\title{
STUDIES ON THE METABOLISM AND TOXICITY OF DINITROTOLUENES

\author{
TOXICOLOGICAL STUDY OF 2, 4- \\ DINITROTOLUENE (2, 4-DNT) IN \\ RATS IN LONG TERM FEEDING
}

\author{
Hiroshi Kozuka, Masa-aki Mori and Yoshifumi Naruse \\ Section of Toxicology, Faculty of Pharmaceutical Sciences, Toyama \\ Medical and Pharmaceutical University, 2630, Sugitani, \\ Toyama, Japan
}

Received July 16, 1979

\begin{abstract}
Dinitrotoluene $(2,4-\mathrm{DNT})$ was incorporated at the level of $0.5 \%$ in a standard commercial diet and fed ad lib. to male rats for 6 months.

Significant changes were noted in the body weight, organ weight, behavior, mortality, and biochemical analysis of blood and serum of rats ingesting 2, 4DNT.

Furthermore, it was found that the ingestion of 2, 4-DNT affected on the activities of drug metabolizing enzymes in liver microsomes.

Key words: Dinitrotoluene, toxicity of nitrocompound, methemoglobin, drug metabolizing enzyme.
\end{abstract}

\section{INTRODUCTION}

Dinitrotoluenes (DNT), one of the commonly used explosives, raw material for brown dyestuff, and intermediate of various reagents, have been produced about $390 t$. in a year. Among the isomers of DNT, 2, 4-DNT is the most important compound and utilized frequently and extensively. Several reports had appeared in the 1940's describing toxic effects in man and animals. For example, McGee et al., (1942) observed symptoms of cyanosis, anemia and jaundice in man. Bredow and Jung (1942) reported the formation of methemoglobin in the plasma of cats after single administration of DNT. Clayton and Baumann (1948) had shown the evidence that fat and protein in diet were distinctly beneficial with respect to growth and survival of mice receiving 2 , 4-DNT. In these studies, however, the toxic effects of DNT in animals fed continuously on a diet containing these compounds for long periods were not reported.

Therefore, in order to investigate the toxicity of $2,4-\mathrm{DNT}$ in detail, we have studied the toxic effects in rats fed with diet containing $0.5 \% 2,4-\mathrm{DNT}$ for six months.

連絡先：道 930-01 笛山市杉谷2630 富山医科薬科大学薬学部 狐塚 筧, 森 正明, 鳴瀬嘉史 
Hiroshi KOzUKA et al.

In this paper we report the change in the body weight, organ weight, behavior, mortality and biochemical analysis of blood and serum of rats ingesting 2, 4-DNT for six months. The influence of dietary 2, 4-DNT on the microsomal drug metabolizing enzymes is also described.

\section{MATERIALS AND METHODS}

1. Experimental animals and their feeding

Animals employed were 7-week-old male rats of Wistar-STD strain purchased from Sankyo Labo. Co., Shizuoka. They were divided into two groups consisting of 20 and 23 animals. 2, 4-DNT of the first grade (Tokyokasei Co.) was further purified by column chromatography. The compound purified was finely ground and mixed into a standard laboratory diet (F-3, Sankyo Labo. Co.) at $0.5 \%$ concentration. The diet containing $0.5 \% 2,4-\mathrm{DNT}$ was given to rats for six months. Control animals consisting of 23 rats were fed the standard diet without 2, 4-DNT. Diet and water were provided ad lib. Animals were individually housed in separate metabolic cages kept in an airconditioned room at a temperature of $24 \pm 3^{\circ}$ throughout a year.

2. Observation of general state

Behavior of the animals, feed consumption, colcur of skin, luster of the hair, and body posture were observed every day as the general state. Body weights of all rats were measured at interval of seven days throughout the experimental time. After an end of experimental period, animals were dissected and the weight of heart, lung, liver, spleen, kidney and testis was measured. Dead rats were also dissected and the organs were observed macroscopically.

3. Methemoglobin and serum biochemical examination

Using blood samples drawn out from the jugular vein, determination of methemoglobin was carried out with cyanmethemoglobin method. Biochemical examinations on the following items were performed by using the serum separated from the jugular venous blood: Triglyceride (enzyme method), blood glucose (o-aminobiphenyl method), total protein (biuret method), albumin (HABA method), GOT (Reitman-Frankel method), GPT (Reitman-Frankel method), LDH (diaphorase method), Al-P (phenylphosphate method), Acid-P (phenylphosphate method).

4. Assay of microsomal drug metabolizing enzymes

The microsomes were isolated from fresh livers according to the method of Cinti et al. (1972). The microsomal precipitates were suspended in $0.1 \mathrm{M}$ phosphate buffer (pH 7.4). The content of microsomal protein was determined by the method of Lowry et al. (1951). The activities of aniline hydroxylase, aminopyrine $\mathrm{N}$-demethylase, and $p$-nitrobenzoic acid reductase were determined by the method described by Imai et al. (1966), Nash et al. (1953), and Bratton and Marshall (1939), respectively. These activities are expressed as per $\mathrm{mg}$ of microsomal protein and per total microsomal protein. 


\section{RESULTS AND DISCUSSION}

1. Diet consumption and body weight

Diets containing $0.5 \% 2,4-\mathrm{DNT}$ were prepared daily and the amount of the nitro compound in the diet was determined by calculation. The average diet consumptions per day in the rats ingesting 2, 4-DNT and control rats were about 13.2 and $14.2 \mathrm{~g}$, respectively for three months of the first half of experimental period, and were about 15.0 and $16.8 \mathrm{~g}$ for three months of the later half of experimental period. This finding indicates that the diet consumption of rats ingesting 2, 4-DNT is approximately comparable to that of control rats. The average 2, 4-DNT consumption per day calculated from these diet consumptions was about $66 \mathrm{mg}$ in the three months of the first half, and was about $75 \mathrm{mg}$ in the three months of the later half of experimental period. From this finding, it is suggested that 2, 4-DNT consumption is gradually increased in proportion to diet consumption with the elapse of experimental time.

In the changes of body weight represented by diet efficency, as shown in Fig. 1, the extent of growth of control rats is tend to increase with the elapse of experimental time, on the contrary, the extent of growth of rats ingesting 2, 4-DNT is tend to decrease and that the tendency of decreasing growth was noticeable at the later half of experimental time.

From this result, it is evident that the rats fed with diet containing $0.5 \% 2$, 4DNT grow less than the control rats.

2. Behavioral symptoms and mortality

In the rats fed with diet containing 2, 4-DNT, the conspicuous symptoms such as piloerection, whitened skin colour, humpback and jerky incoordination were appeared about at the three months, the half time of experimental time, in addition, the decrease of spontaneous movements or general weakness were also observed.

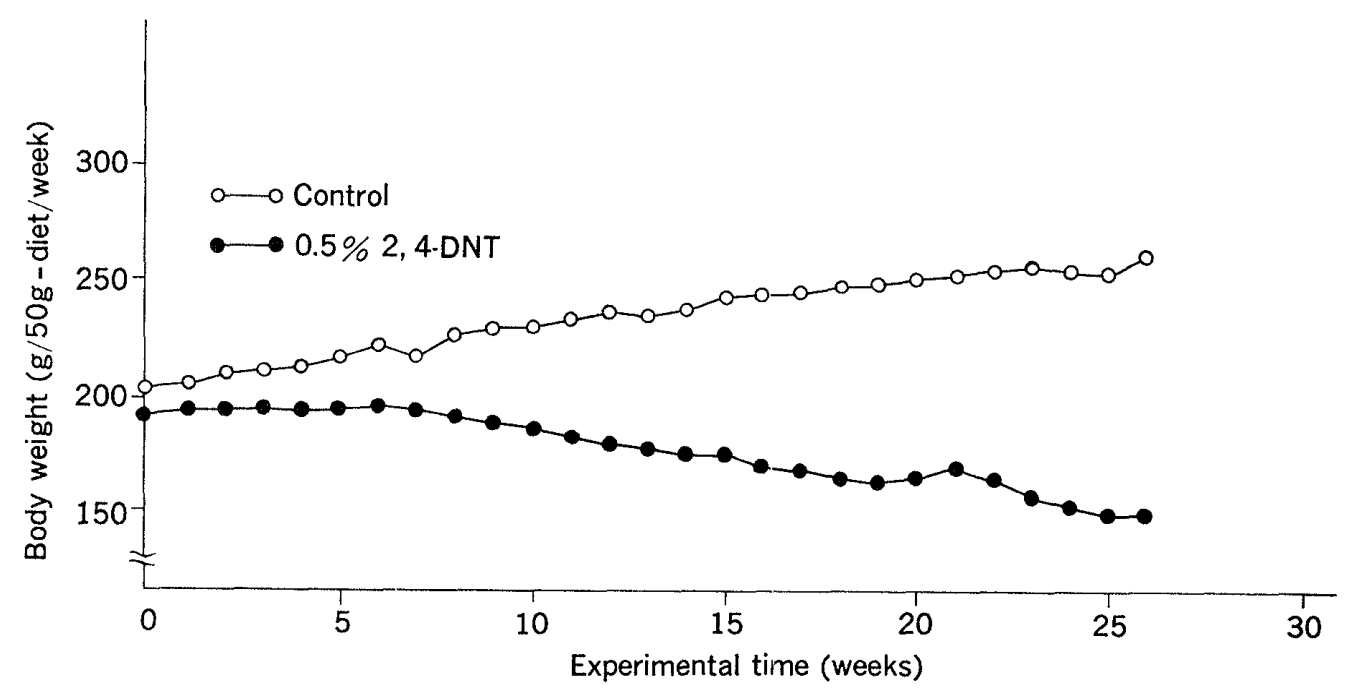

Fig. 1. Change in body weight by average 50g-diet per week 


\section{Hiroshi KozUKA et al.}

The number of weekly fatality of rats was observed during the 26 weeks. As shown in Table 1, the died time of rats ingesting 2,4-DNT was inclined at the later half of experimental period. Eventually, the mortality of the rats fed with diet containing $0.5 \% 2,4$-DNT was about $71 \%$ for 26 weeks.

From these findings, it is suggested that the obvious toxic effects contributed to the ingestion of 2, 4-DNT are revealed about at the three months from the start of the experiment, under the condition of our experiment.

3. Effect of 2,4-DNT on the relative organs weight and macroscopical findings of the organs.

The organ weights of the rats ingesting 2, 4-DNT were compared with those of the control rats at the end of the experiment. The result is presented in Table 2.

No significant differences were observed in the relative weight of the heart and lung between the rats ingesting 2, 4-DNT, however, the relative weights of liver, spleen and kidney are significantly increased, showing about two-fold increase compared with those of control rats. While the relative weight of testis of rats ingesting 2, 4-DNT was markedly decreased compared with that of control rats.

As the macroscopical findings, the formation of puruloid matters was observed in the liver of rats ingesting 2,4-DNT (Fig. 2). In addition, the testicular atrophy was also observed in the rats ingesting 2,4-DNT. In regard to the other organs, there were no lesion in the macroscopical observation.

From these findings, it is assumed that the liver and kidney, metabolic and excretive

Table 1. Weekly fatality of rats fed with diet containing 2,4-DNT during the 26 Weeks

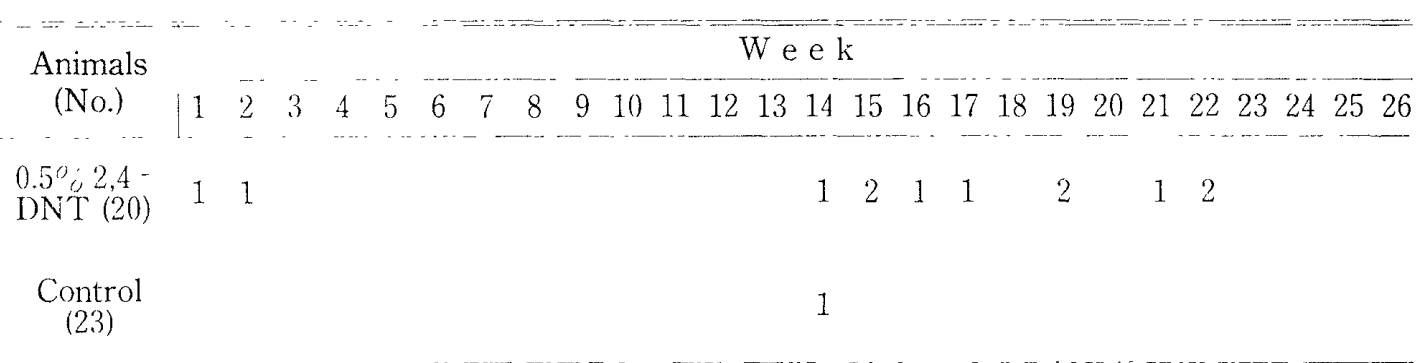

Table 2. Effect of dietary 2, 4-DNT on the organ weight of rats

\begin{tabular}{|c|c|c|c|c|c|c|}
\hline \multirow{2}{*}{ Animals ( $\mathrm{No}$.) } & \multirow[b]{2}{*}{ Heart } & \multicolumn{4}{|c|}{ Organ weight ( $g / 100 \mathrm{~g}$ of body weight) } & \multirow[b]{2}{*}{ Testis } \\
\hline & & Lung & Liver & Spleen & Kidney & \\
\hline $\begin{array}{c}0.5 \div, 2,4-\mathrm{DNT} \\
(20)\end{array}$ & $0.505 \pm 0.011$ & $0.638 \pm 0.075$ & $7.668 \pm 1.402^{* * *}$ & $0.234 \pm 0.084^{* * *}$ & $1.181 \pm 0.081^{* * *}$ & $0.383 \pm 0.062^{* * *}$ \\
\hline $\begin{array}{l}\text { Control } \\
\text { (23) }\end{array}$ & $0.386+0.059$ & $0.570 \pm 0.101$ & $3.957 \pm 0.656$ & $0.123 \pm 0.021$ & $0.682 \pm 0.079$ & $0.668 \pm 0.173$ \\
\hline
\end{tabular}

Rats were fed with diet containing $0.5 \%$, 2,4-DNT for 6 months. Data represent mean value \pm standard deviation and significant difference is at $\mathrm{p}<001\left(^{* * *}\right)$ as compared with control value. 
organs, and testis are target organs for the toxic actions in the rats fed with diet containing 2, 4-DNT for long periods.

4. Effect of dietary 2, 4-DNT on the formation of methemoglobin, and serum components and serum enzymes

Table 3 lists the result of methemoglobin examination at the end of the experiment. The formation of methemoglobin in the rats ingesting 2, 4-DNT was significantly increased and the amount of methemoglobin was about 7 times that of the control rats.

As described at the beginning, Bredow and Jung (1942) reported the formation of methemoglobin in the plasma of cats after single administration of 2,4-DNT but the data on the animals fed continuously on a diet containing this compound for long periods were not reported. From this result, however, it is evident that the amount of methemoglobin of the blood of rats fed with diet containing $0.5 \% 2,4$-DNT for 6 months is increased significantly compared with control rats.

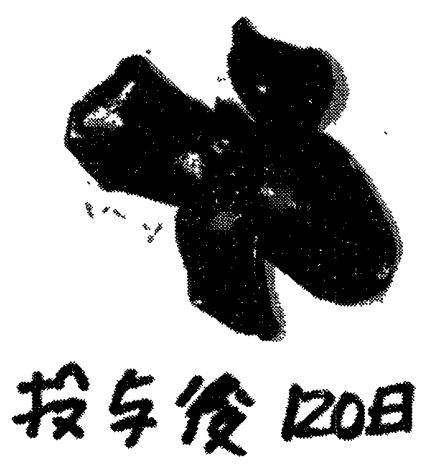

Fig. 2. Formation of puruloid matters in liver of rats at 4 months after dietary administration of 2,4-DNT

Table 3. Effect of dietary 2,4-DNT on the formation of methemoglobin in blood of rats

$\begin{array}{cc}\text { Animals (No.) } & \text { Amount of methemoglobin }(0 ;) \\ 0.5 \%, 2.4-\mathrm{DNT}(5) & 7.01 \pm 1.56^{* * *} \\ \text { Control (16) } & 1.13 \pm 0.27\end{array}$

Rats were fed with diet containing $0.5 \% 2,4$-DNT for 6 months. Data represent mean value \pm standard deviation and significant difference is at $\mathrm{p}<0.01\left(^{* * *}\right)$ as compared with control value. 
Hiroshi KOZUKA et al.

Table 4. Effect of dietary 2,4-DNT on the biochemical findings of serum components and serum enzymes

\begin{tabular}{|c|c|c|c|c|c|c|c|c|c|c|}
\hline $\begin{array}{c}\text { Animals } \\
\text { (No.) }\end{array}$ & $\begin{array}{l}\text { Triglyceride } \\
\qquad(\mathrm{mg} / \mathrm{dl})\end{array}$ & $\begin{array}{l}\text { Blood } \\
\text { glucose } \\
(\mathrm{mg} / \mathrm{dl})\end{array}$ & $\begin{array}{l}\text { Albumin } \\
(\mathrm{g} / \mathrm{dl})\end{array}$ & $\begin{array}{l}\text { Total } \\
\text { protein } \\
(\mathrm{g} / \mathrm{dl})\end{array}$ & $\mathrm{A} / \mathrm{G}$ & $\begin{array}{l}\text { GOT } \\
\text { (Karm }\end{array}$ & $\begin{array}{l}\text { GPT } \\
\text { en } U)\end{array}$ & $\begin{array}{l}\text { LDH } \\
\text { (Wrobl- } \\
\text { ewski U) }\end{array}$ & $\begin{array}{l}\text { Alkaline } \\
\text { P-ase } \\
\text { (K-A }\end{array}$ & $\begin{array}{l}\text { Acid } \\
\text { P-ase } \\
\text { A U) }\end{array}$ \\
\hline $\begin{array}{c}0.5^{\circ}, 2,4-\mathrm{DNT} \\
(5)\end{array}$ & $\begin{array}{l}221.7^{* * * *} \\
\pm 26.1\end{array}$ & $\begin{array}{l}185.7^{* * *} \\
\pm 2.8\end{array}$ & $\begin{array}{l}2.06^{* * *} \\
\pm 0.16\end{array}$ & $\begin{array}{r}5.04 \\
\pm 0.23\end{array}$ & $\begin{array}{l}0.70^{* *} \\
\pm 0.10\end{array}$ & $\begin{array}{l}110.0^{* *} \\
\pm 1.40\end{array}$ & $\begin{array}{r}25.15 \\
\pm 1.63\end{array}$ & $\begin{array}{l}517.3^{* * *} \\
\pm 18.6\end{array}$ & $\begin{array}{l}39.73^{* *} \\
\pm 4.34\end{array}$ & $\begin{array}{l}17.23^{* * *} \\
\pm 0.35\end{array}$ \\
\hline $\begin{array}{c}\text { control } \\
\text { (5) }\end{array}$ & $\begin{array}{l}34.83 \\
\pm 5.77\end{array}$ & $\begin{array}{l}154.7 \\
\pm 3.30\end{array}$ & $\begin{array}{r}3.24 \\
+0.13\end{array}$ & $\begin{array}{r}5.19 \\
\pm 0.24\end{array}$ & $\begin{array}{r}1.70 \\
\pm 0.31\end{array}$ & $\begin{aligned} & 81.33 \\
\pm & 6.51\end{aligned}$ & $\begin{array}{r}28.00 \\
\pm 1.50\end{array}$ & $\begin{array}{r}398.0 \\
\pm 34.0\end{array}$ & $\begin{array}{r}24.40 \\
\pm 3.05\end{array}$ & $\begin{array}{r}10.63 \\
\pm 0.21\end{array}$ \\
\hline$: 0$ of control & 637 & 120 & 64 & 97 & 41 & 135 & 90 & 130 & 163 & 162 \\
\hline
\end{tabular}

Rats were fed with diet containing $0.5 \% 0$ 2,4-DNT for a month. Data represent mean value \pm standard deviation and significant differences are at $\mathrm{p}<0.01\left({ }^{* * *}\right)$ and $\mathrm{p}<0.02\left({ }^{* *}\right)$ as compared with control values.

Table 5. Effect of dietary 2,4-DNT on the activities of microsomal drug metabolizing enzymes

\begin{tabular}{|c|c|c|c|c|c|}
\hline Animals (No.) & Liver $(g)$ & $\begin{array}{l}\text { Microsomal protein } \\
(\mathrm{mg}) / \mathrm{g} \text { liver }\end{array}$ & Aniline hydroxylase & $\begin{array}{l}\text { Aminopyrine } \\
\text { N-demethylase }\end{array}$ & $\begin{array}{l}\text { p-Nitrobenzoic } \\
\text { acid reductase }\end{array}$ \\
\hline & & & \multicolumn{3}{|c|}{ per mg of microsomal protein (n mole $/ 20 \mathrm{~min}$ ) } \\
\hline $0.5: 2,4-\mathrm{DNT}(4)$ & $14.1 \pm 1.6$ & $19.50 \pm 3.41$ & $5.96 \pm 0.10$ & $7.50 \pm 0.28^{* * *}$ & $0.88 \pm 0.76^{* *}$ \\
\hline Control (4) & $10.6 \pm 3.8$ & $14.95 \pm 1.30$ & $6.71 \pm 0.74$ & $10.67 \pm 0.36$ & $3.25 \pm 1.36$ \\
\hline
\end{tabular}

per total microsomal protein $(\mu$ mole $/ 20 \mathrm{~min})$

$\begin{array}{llll}0.5 \% 2,4-\mathrm{DNT} & 1.63 \pm 0.03^{* * *} & 2.06 \pm 0.08^{* * *} & 0.151 \pm 0.06^{*} \\ \text { Control } & 1.06 \pm 0.12 & 1.69 \pm 0.06 & 0.513 \pm 0.215\end{array}$

Activities of aniline hydroxylase, aminopyrine $\mathrm{N}$-demethylase and $p$-nitrobenzoic acid reductase as $p$-aminophenol formed from aniline, formaldehyde released from aminopyrine and $p$-aminobenzoic acid formed from $p$-nitrobenzoic acid, respectivery. Rats were fed with diet containing $0.5 \% 2,4$-DNT for a month. Data represent mean value \pm standard deviation and significant differences are at $\mathrm{p}<0.01\left(^{* * *}\right), \mathrm{p}<002\left(^{* *}\right)$ and $\mathrm{p}<0.05\left(^{*}\right)$ as compared with control values.

The present authors (Kozuka et al., 1978) have demonstrated that the 2, 4-DNT is principally converted to two monoaminonitrotoluenes by rat liver homogenate. Based on this and the present result, it is suggested that the formation of methemoglobin is attributable to the nitroso and hydroxylamino forms, intermediates of monoaminonitrotoluenes.

In the following, the rats fed with diet containing 2, 4-DNT for a month were tested for serum components and serum enzymes. As shown in Table 4, the contents of triglyceride and blood glucose were significantly increased, on the contrary, the content of albumin and the ratio of $\mathrm{A} / \mathrm{G}$ were significantly decreased. In addition, all 
Metabolism and toxicity of dinitrotoluenes.

serum enzyme activities except GPT activity were also increased significantly.

As a result, significant changes were observed in all of items examined except GPT. and total protein, and this indicates that ingesting 2,4-DNT may induce the various disease with their functional damages in the liver, kidney and bone.

5. Effect of dietary 2,4-DNT on the microsomal drug metabolizing enzymes

The content of microsomal protein and the activities of drug metabolizing enzymes in microsomes are presented in Table 5, for male rats fed with diet containing $0.5 \%$ 2, 4-DNT for a month. The liver weight and the content of microsomal protein per liver weight increased markedly in the rats ingesting 2, 4-DNT. Though the aniline hydroxylase and aminopyrine $\mathrm{N}$-demethylase activities per $\mathrm{mg}$ of microsomal protein were unchanged and slightly decreased, respectively, the activities of the two enzymes expressed as per total microsomal protein were slightly increased. On the other hand, $p$-nitrobenzoic acid reductase was decreased markedly in its activity either per $\mathrm{mg}$ of microsomal protein or per total microsomal protein.

As a result, besides no significant change in aniline hydroxylase activity and aminopyrine $\mathrm{N}$-demethylase activity, $p$-nitrobenzoic acid reductase was decreased markedly by the dietary administration of $2,4-\mathrm{DNT}$ for a month. This finding suggests that the microsomal oxidase keeps the activity of approximate control level, but the reductase activity of liver microsome is markedly decreased by ingesting 2, 4-DNT.

Inevitably, further investigation are needed which would characterize the oxidation and reduction metabolites of 2,4-DNT mediated by microsomal drug metabolizing enzymes for an understanding of the mechanism of the toxic actions of this compound.

\section{CONCLUSIONS}

Poisoning symptoms, biochemical changes in blood and serum, and changes in microsomal drug metabolizing enzymes in rats fed with diet containing 0.5\% 2, 4-DNT were investigated as a step in the study of the metabolism and action of DNT and the following results were obtained.

1. Dietary administration of $2,4-\mathrm{DNT}$ is allowed to depress the increase of the body weight.

2. Mortality was about $71 \%$ for the six months.

3. As the conspicuous poisoning symptoms, humpback, jerky incoordination, piloerection and whitened skin colour were observed.

4. On the macroscopical findings, formation of puruloid matter was seen in the liver. Hypertrophy was seen in liver and atrophy was seen in testis.

5. Amount of methemoglobin was increased at seven-fold of control level.

6. Activities of serum enzymes except GPT were increased significantly and content of albumin and ratio of $A / G$ were decreased significantly.

7. On the microsomal drug metabolizing enzymes, no significant change was observed in aniline hydroxylase activity and aminopyrine $\mathrm{N}$-demethylase activity, however, $p$ - 


\section{Hiroshi KozUKA et al.}

nitrobenzoic acid reductase was decreased markedly by the dietary administration of 2, 4-DNT.

\section{ACKNOWLEDGMENTS}

We are grateful to Miss Reiko Hayashi and Mr. Shigeru Namikawa for their excellent assistance in this University.

\section{REFERENCES}

Bratton, A.C. and Marshall, F.K. (1939). A new coupling component for sulfanilamide determination. J. Biol. Chem., 128, 537-550.

Bredow, M.V. and Jung, F. (1942). Studien über Methämoglobinbildung. Naunyn-Shmidebergs Arch., 200. 335-355.

Cinti, D.L., Moldeus, P. and Schenkman, J.B. (1972). Kinetic parameters of drug-metabolizing enzymes in $\mathrm{Ca}^{2+}-$ sedimented microsomes from rat liver. Biochem. Pharmac., 21, 3249-3256.

Clayton, C.C. and Baumann, C.A. (1948). Effect of fat and calories on the resistance of mice to 2, 4-dinitrotoluene. Arch. Biochem. Biophys., 16, 415-422.

Imai, Y., Ito, A. and Sato, R. (1966). Evidence for biochemically different types of vesicles in the hepatic microsomal fraction. J. Biochem., 60, 417-428.

Kozuka, H., Mori, M., Katayama, K., Matsuhashi, T., Miyahara, T., Mori, Y. and Nagahara, S. (1978). Studies on the metabolism and toxicity of dinitrotoluenes-Metabolism of dinitrotoluenes by Rhodotorula glutinis and rat liver homogenaet. Eisei Kagaku, 24, 252259.

Lowry, O.H., Rosebrough, N.J., Farr, A.L. and Randall, R.J. (1951). Protein measurement with the Folin phenol reagent. J. Biol. Chem., 193, 265-275.

McGee, L.C., McCausland. A., Plume, C.A. and Marlett, N.C. (1942). Metabolic disturbances in workers exposed to dinitrotoluene. Am. J. Digestive Disease Nutrition. 9, 329-332.

Nash, T. (1953). The colorimetric estimation of formaldehyde by means of the Hantzsch reaction. Biochem. J. 55, 416-421. 